\title{
Imreh István \\ Az „úrdolgás világ”, Kossuth Lajos és negyvennyolc a bálványosváraljaiak emlékezetében ${ }^{177}$
}

\author{
„Nagyon szívós a nép emlékezete, hallgat, \\ de nem felejt, s e nemfeledés hagyományilag \\ nemzedékröl-nemzedékre száll..."
}

Kossuth Lajos

Erdélyben 1848 Szentháromság vasárnapján, június 18-án a közel 1400000 főnyi jobbágy megszünt robotoló, „úrdolgás”, „paraszt” lenni. A feudalizmus rendszerének, a „rendi” társadalom szerkezetének tartóoszlopai meginogtak, majd porba hulltak. A nagy változás, a polgári átalakulás lehetőségei megnyíltak, és lassan ugyan, de új rend építkezhetett a romokon.

A bálványosváraljai falukutatás ${ }^{178}$ során meggyőződhettünk arról, hogy ennek a SzolnokDoboka megyei falunak a népe is a jobbágyság felszabadítását tartja 1848 nagy teljesítményének, és Kossuth Lajost tekinti a „régi világ” felett aratott győzelem vezérének. Elöljáróban még csak azt szeretnők hangsúlyozni, hogy a bálványosváraljai falukutatók közel egy évszázaddal az események után faggatták, meséltették a falu népét, én pedig most, egy újabb fél évszázad múltán idézem szavaikat.

\section{Kik voltak Bálványosváralja urai?}

A váraljai falukutatók a jelent magyarázó tényezőket keresték a múló időre emlékezők szavaiban. A földesurak, a birtokosok felől is a jobbágyokkal való viszonyuk miatt érdeklődtek, hogy lássák: őrzik-e emléküket és miként vélekednek róluk.

\footnotetext{
${ }^{177}$ A kolozsvári egyetemi hallgatók 1941-1944 közötti években kísérelték meg - Venczel József vezetésével - a bálványosváraljai falumonográfia megalkotását. A „falukutatása” befejezetlen maradt. Az összegyüjtött anyagot az EME Levéltárában helyeztük el. A rendszerezett, dobozokba témakörök szerint elrendezett anyag - Venczel József bebörtönzése után - hozzáférhetetlenné vált. A Kossuth Lajosra emlékezés napjaiban sírja mellé szerettük volna megidézni a hajdani paraszti nép utódait is. Így született meg ez az írás, a fél évszázaddal ezelötti jegyzetfüzetek, a gépeltetésre, tanulmányozásra a törzsanyagból kiszedett cédulák alapján. Az „úrdolgás világ”, a feudális életformára való emlékezés - a közgazdaság, néprajz és történelem egybeszövődöttsége miatt is - az én kutatási területemmé vált. Mint ahogyan Markos Andrásnak jutott a szektás mozgalom, Tárkány Szücs Ernőnek a jogszokások, Vincze Lajosnak a népdalok, Molter Péternek a hiedelmek vizsgálata és így tovább. Miután a gyüjtést befejeztem, a korosztályok, társadalmi rétegek, csoportok ellenőrzését Wass Judit végezte el, majd Szigyártó Sándor egészítette ki a hézagos részeket. Az első kiszálláskor készített jelzések, „probléma-feltáró cédulák” szintén nagy segítségemre voltak.

${ }^{178}$ A bálványosváraljai falukutatás irodalmához bevezetőként 1. Venczel József: Az önismeret útján. Buk. 1980. 14-20, 137-141, 182-183. Legutóbb Venczel József születésének nyolcvanadik évfordulója alkalmával jelentek meg a váraljai monográfia-kísérletet is említő írások, hangzottak el értékelő előadások, 1. pl. Müvelődés XLVI(1994). 2. sz.
} 
„Az egész község az uradalomé volt” - mondták. Ezt a nagyon távoli régiségben „Bálványos vára" testesítette meg, ahol olyan óriások laktak, akik egyik hegyről a másikra lépegettek, ahol az óriáskirály lánya apjának kötényébe szedegetett apró embereket mutogatott, akiket azután még a tatároktól is oltalmazni szeretett volna. A regék, mondák hiedelemvilágának ködébe burkolt valós elemek azután vajdák, fejedelmek regnálására utalnak, s arra, hogy a falu a várbirtok része volt. 1553 táján már csak romosodott maradványai vannak a várnak, $\mathrm{s}$ köveiből épül örököse, a szamosújvári erősség, amelynek ez a falu is tartozéka volt.

A fiskus birtokosztogatása rendjén jelentős részét ifjú Apafi Mihály adományozza Bánffy Györgynek. Különben sokasodnak az urak. Még Misztótfalusi Kis Miklós is tulajdonosává válik itt egy malomrésznek. ${ }^{179}$

A XVIII. század derekán féltucatnyi föúri család, Szamosújvár és néhány kisnemes tekinthető Váralja birtokosainak. 1820-ban a kereskedők e gazdag városának 40 jobbágytelke van. A szomszédos szentbenedeki kastély urai, a Kornisok 53 jobbágyot robotoltatnak. 15 úrdolgás felett új birtokos, a Herszényi család rendelkezik. ${ }^{180}$ Ök 1771-ben a fiskussal cserélik el Fogaras-vidéki örökségüket. Jósika Jánosné Csáky Rozáliának 29 parasztcsalád tesz szolgálatot. Ö az, aki Kolozsvárnak sétateret szervez, selyemfilandát, dologházat létesít. ${ }^{181}$ Oly tevékeny, hogy úti kocsijába „,́róasztalt” készíttet, hogy ott is feljegyzéseket tehessen vagy éppen Wesselényi Miklósnak írjon. 1842-ig Kornis János gubernátor ${ }^{182}$ a leghatalmasabb, nagy tekintélyü férfiú, akiről feltehető, hogy Csáki Rozáliával egyetemben élhet a tudatokban. A falu népének emlékezetében azonban őket hiába keressük: nincsenek. Oka lehet 48 előtti abszentizmusuk és az, hogy a harcok után lassan eladogatták jussukat.

A feudalizmus földesurairól szólva sok történet, 1943-ban még el-elmondott história hösei viszont a Herszényiek. Ök birtokot, örökséget elpazarló, a hulló úri réteg típusához tartoztak. Utolsó nagyasszonyukat a katolikus pap támogatta, fiát, Lászlót a falu tartotta „kegyelemkenyéren". Fennmaradt a híre a szamosújvári Pap családnak, amelyik Váraljára is kiköltözött, és annak grófi birtokosaitól vett, bérelt jobbágytelkeket. Igaz, Pap Jenő úr maga is mesélte (1943-ban még élt) nagyapja, Pap Márton 48-as dolgait, bajait.

Az urakra emlékezőknek, a kastélyuk árnyékában élőknek csak egy vékony rétege tud a Kornisokról. Az időpontok azonban bizonytalanok, tévesek, Például: „égy vélem, 300 évvel ezelött még mindig a Kornisé volt”; vagy: „1872-ben, Mária Terézia alatt Váralja nagyrészt Kornis-birtok volt. A Kornisok adogatták el, s az örmények vették meg." A többség semmi valósághoz közelítőt nem tud mondani, és az időkereteket felbontva, első világháború előtti urakkal népesíti be az 1848 elötti korszakot.

Ugyanakkor hajdani robotoltatóikat csendes beletörődéssel, kényszerü szükségszerüségként fogadják el. Nem szidják, nem gyülölik, de azért úgy fogalmaznak: „A régi világban voltak az emberek és a nemesek, az urak." A távolság mérhetetlenül nagy volt. Az uradalmi tisztek, a botosispánok, a hajtók már közelebbiek, de egymáshoz hasonlóak, arc és név nélküliek. Szolgák ök is, „botok” gazdáik kezében.

${ }^{179}$ Bálványosváralja történetére vonatkozólag 1. Tagányi Károly-Réthy László-Pokoly Viktor-Kádár József: Szolnok-Doboka vármegye monográfiája I-VII. Dés 1901-1905. (A továbbiakban rövidítve: SzD.) L. még: Szolnok-Doboka magyarsága. Szerk. Szabó T. Attila. Dés-Kolozsvár 1944. Hodor Károly: Doboka vármegye természeti és polgári esmértetése. Kvár 1937. Szongott Kristóf: SzamosLjvár szab. kir. város monográfiája I. Szamosújvár 1901.

${ }^{180}$ SzD. IL. 122.

${ }^{181}$ Vö. Csizmadia Andor: Szociálpolitika a reformkori Kolozsváron. Kvár 1943. 4-41.

${ }^{182}$ Klima, Helmut: Guvernatorii Transilvaniei. Sibiu 1943. 17-19. 


\section{Kisnemesek, darabontok}

Mi falukutatók 1943 táján, a sok évszázados jobbágyi életformát a türés, a beletörődés vagy éppen meghunyászkodás egyik - történelmi fogantatású - meghatározójának tekintettük. A vízözönnel, tatárokkal is megküzdő óriások, a várnagyok, a földesurak jóindulatát szorongva esdő alávetettek mellett Bálványosváralján azonban katonáskodó szabadparaszti népréteg is lakott, az úgynevezett darabontok: a szamosújvári vár puskásai, szabadosai, majd a fiskus taxásai. 1612-ben 15-öt, 1715-ben 18 nemzetséget számláltak össze. Földjük nem sok volt; a 11 telek után járó szántó 10-10 köbölnyi, de szőlöjük már bővebben volt, és sok állatot tartottak; átlagosan 5 ökör, 2 tehén, 1 borjú, 7 disznó, 2 méhköpü jutott egy telekre. ${ }^{183}$ Számukat pontosan azért is nehéz megállapítani, mert a kisnemeseket is gyakran közéjük sorolják. 1838-ban a lajstromozó szerint 82 magyar és 2 „oláh ajkú nemes” személy lakik e faluközösségben. Közülük 13 nem adózó - módosabb -, és 12 az írni-olvasni tudó tanultabb. Az 1866-os kimutatás 49 családot, 173 személyt sorakoztat fel. ${ }^{184}$

A rájuk egy évszázad múltán emlékező falu hagyományállaga szegényesebb és pontatlanabb a székelyföldiekénél, de az úrdolgás életforma normáitól eltérő jelenség az, ami „mai” szemmel nézve számunkra különös vagy éppen kuriózum, meseszerüen él, méghozzá elég széles körben. Ilyenformán: „A magyarok, mikor ide béjöttek, lóhátról védték a hazát, és ki milyen szolgálatot tett, úgy kapta a földeket ... már akkor megvoltak a darabontok.” Ök „első emberek”, „kiváló emberek” voltak és „katonák”. Ezért volt jussuk - mondották - szabad, saját telekhez, földhöz. Egyesek úgy tudták, hogy úrdolgás lányt feleségül el sem vehettek, hogy ne szüküljön, ne csappanjon meg a katonáskodó szabad embert eltartó földmennyiség.

Egy periratban 1804-ben úgy definiálják őket: „Darabontok, akik a fiskus jussát bírják s ezért taxát, dézmát fizetnek a szamosújvári közönségnek." "185 Várvédő katonai szerepüket ekkor tehát már elvesztették, hiszen az erősség máig nevezetes börtönné változott. Megmaradt viszont a váraljai darabont telkek után járó kiszakított, külön erdőrész, a „darabont erdő”. De értetlenül emlegetik az „antikfát”, a „fiskus nyilat”. Ugyanakkor belső telkük is nemesi immunitást élvező; a kötéllel katonát fogók elől az ilyen darabonti telekre menekülő után nem hatolhatott be a toborzó katona.

A lényeges azonban az, hogy a volt darabontok közül is sokan tudják: ők előkelőbb származásúak. A kisnemesekröl nem is szólva. A legtöbbet a Tarcza-Tamás, Ladár, Boér, Kádár, Szabó, Engi családokat emlegették, akik szürke harisnyát viseltek s szavazati joggal éltek. Több közülük román eredetü volt. Ioan Rus szerint: „Azok nem is voltak úrdolgások, olyanok voltak, mint Romániában régen a bojárok." Össze is házasodtak a magyar szabadrendiekkel, s egy-egy család - mint például a Tarczák - fel is jutottak a magyar nemességbe.

A darabontok másságát is elmondották, azt, hogy „gálántabb”, „luxusra adó”, ruházatra többet költő, szebben beszélő és nagyurakkal is harcba szálló emberek. Ezek - Pap Jenő birtokos úr szerint - „,́rás-, olvasás-tudó emberek voltak. Nagyobbszájúak. Ezeket használta fel a község, ha valamit ki akart vinni. Ezek bölcselkedtek.” 1804-ben Kornis Zsigmond ellen - a közhelyek felosztásakor az erdőhasználati jogért - Engi István vezetésével harcolt a falu; ő a gubernium elé vitte ügyüket, és Bécsig is eljárt.

\footnotetext{
${ }^{183}$ SzD. II. 113, 117.

${ }^{184}$ I. m. 135.

${ }^{185}$ KvÁLvt. ENMLvt. Gönczruszkai gróf Kornis cs. lvt. 981. doboz. (A továbbiakban: Kornis cs. lvt.). A gazdasági és társadalmi viszonyok forrásai közül, a rendkívül gazdag anyagból (ugyanabban a levéltári megőrzésben) csak a következőket említenők: Bánffy cs. lvt. U. C. Fasc. I. nr.1. (1720), 10 (1803), 14 (1824); U. C. Fasc. III. nr.10. (Kemény összeírások); U. C. Fasc. XVII. nr.7.
} 
A kisnemesek és darabontok viszonyára jellemző, hogy a falu igazgatásában közösen vesznek részt. 1801-ben Szőke János az egyházi nemesség és darabontság nagy hadnagya, a vicehadnagy Madán Todor, a falusbíró Timár István, nótárius pedig a nemesi jussal élő Nagy Ferenc.

Deák János szerint ez a társadalmi csoport „,a felszabadulás” után „gálasággal, munkanélküliséggel, birtoknélküliséggel” maradt, és ,a jobbágy lépett előtérbe”.

\section{Az úrdolgások}

A jobbágyvilág paraszti emlékképének summája az az ítélkezés, amelyet háborús időben úgy fogalmaz meg egy elkeseredett váraljai asszony, Vas Incze Sándorné: „Egy nagy úrdóga ez a mai világ." Arra a kérdésre, hogy akkor volt-e jobb az élet, vagy ma, nagyon sokan mondották „mégis csak jó volt a felszabadulás”, mert az ember végre magának termelhet, s azok, ,akik ilyen jobbágyok voltak, azokat mégis csak bántotta az, hogy szabadon nem lehet semmijük". Orbán István szerint a szabadulás után mind csak jobb lett, mert „,nem parancsoltak”.

Tulajdonosi jussal élni, szabadnak lenni, parancsok jármát levetni: nagy-nagy fordulat a paraszti életformában. Néhányan említik csak, hogy nem is volt minden eresztékében rossz az úrdolgás világ. Ök gazdasági viszonyokra gondolnak. Visszaemlékeznek olyan apai, nagyapai elbeszélésekre, amelyek a nyomásos rendszert, a kétfordulós határt, a legelőbőséget, jó állattartási feltételeket $\mathrm{s}$ általában a kipróbált életkeret adta biztonságot, kiszámíthatóságot dicsérték.

Mindenesetre jellemző, hogy a jobbágyi sorsot, a szolgáltatások közül a robotot milyen sokan tudták részletesen visszaidézni.

Erdélyben úrbérrendezés nem volt. ${ }^{186}$ A jobbágyok szolgáltatásait útmutató diétai, udvari jogszabályok s föleg az úr és paraszt közötti egyezség vagy a hagyomány, a szokás döntötte el. Váralján tudták, hogy egy-egy telekért hány napot kell robotolni. Nagyobb jószágért több úrdolgát tettek.

Jóllehet számottevő a változatosság, és a földesurak robotnövelési törekvései is sokasodnak, az 1840. évbeli „Nyilak könyve” szerint a Kornisok váraljai jobbágyai és zsellérei közül 34en heti 2 napot, 15-ön 1 napot és egy hurubás évi 36 napot dolgozik. ${ }^{187}$ Martonos János úgy tudja, hogy: „Kellett szántani, kaszálni kapálni, aratni, fát vágni, szőlőben dolgozni, az ökrösnek ganét hordani, hordót vinni a szőlöbe, a béres szekerek mellé állni...” „Napfelkeltétől csillagfeljöttéig."

Nem él az emlékezetekben a robothoz hasonló részletességgel és élességgel a dácia és dézma képe, holott bizonyos, hogy például 1841-ben 2 véka zab, 2 kappannak való csirke, 10 tojás ajándékot kellett beszolgáltatni és emellett még fonni, szőni is. „Sarló alá való és csős gabonából" dézmába adtak, de az ispáni feljegyzésekben kender, kendermag, fuszujka, bor, bárány is szerepel. ${ }^{188}$ „Ha volt tíz tyúkom - meséli Martonos János -, egyet elvett [az úr], ha volt tíz zsák málém, egyet elvett. Mindenből.” (A lánya értetlenül, csodálkozva kérdi: „Miért nem ment a bírósághoz?” - „Akkor nem mehettél” - inti le az apja.)

\footnotetext{
${ }^{186}$ Trócsányi Zsolt: Der Versuch zur Urbarial reglementierung von 1819-1822 in Siebenbürgen. Revue Roumaine d'Histoire. VIII(1969), 705-722.

${ }^{187}$ Kornis cs. 1vt. 998. doboz. A „Nyilak könyve”.

${ }^{188}$ Uo. 983. doboz.
} 
A kiszolgáltatottságot, az alávetettséget nehezen feledik a váraljaiak, különösen a verést, a „botütést”. Emlékeznek rá, hogy a „munkára nem menő” kapott 25-öt, „,de jót”. „Ha az úrbéres nem dolgozott tisztességesen, akkor a tiszttartó azt mondta »bukk meg« aztán lefogatta két béressel, és ráhúzta a 25 botot.” „A sarkától a nyakáig verték. A »bank « fél méter körüli volt. A bankot láttam. Olyan volt, mint az uraknál a porozó, csakhogy törpe volt, derékig ért. Arra buktaták le, és verték" Szembeszállásról, lázadásról soha senki sem hallott. Holott éppen a 48 előtti fél évszázadban valóban megnehezedett a jobbágysors. Kornis Zsigmond például a XIX. század első évtizedében lázasan növeli allódiumát. Városba, hivatalba gravitáló kisnemesek jószágát vásárolja fel. 1808-ban az egész falu lakosságát vármegyei tisztekkel hívattatja össze és közli velük, hogy bárki, bármiféle címen - irtás, zálog, foglalás révén - az ő majorsági földjét bírja: jelentse be. Súlyossá e jogcímrendezést az teszi, hogy a gróf nagymértékben kiterjeszti az allodiális föld fogalmát. Minden hajdani közföldböl foglalt, irtott, használatban megtartott „falu földjét” tulajdonának tekinti. Olyannyira, hogy a kisnemeseket és darabontokat is rá akarja szorítani arra, hogy szolgáltassák be a „részére tartozandó dézmát a falu fölgyeiből". ${ }^{189}$ Az erdőket is magának vindikálja, de mint láttuk, a szabados Engi István vezetésével ekkor már fellázad a falu. Több igás napszámra lévén szüksége, közli 2 jobbágyával, hogy ha ökröket nem szereznek és gyalog-, valamint tehenes robot helyett nem tesznek ökrös hétszámot, jobbágyörökségeiket elveszi és másoknak adja. A kocsmárlás hagyományos rendjét is megbontja. 14 váraljai cégért vetet be a megyei tisztekkel, olyanokét, akik a faluközösség tagjaiként boraik kimérését szabadnak vélték.

Mindazok az ellentétek, amelyek a feudalizmus utolsó évtizedeiben sokasodtak és gátolták az összefogást, az érdekegyesítést, nem oldódtak meg az 1848 tavaszán és nyarán születő törvénycikkek hatására sem. Kossuth azonban „,a szabad föld apostola” lett és maradt. „Isten áldja meg a porát is annak, aki felszabadított" - mondották a váraljaiak majd egy évszázad múltán is.

\section{A felszabadítás. Kossuth Váralján}

A jobbágyfelszabadítást a váraljaiak nem tekintik a „népi erők”, a maguk művének és még kevésbé a „Habsburg-birodalom császára” jótéteményének. Akkor szerintük: „Rabok voltak az emberek, csak éppen hogy nem szántottak velük. De igába voltak! Mit tehettek volna?” A megváltást hozó nagy fordulatot ily módon valaki nagy ember, legendás alak cselekedeteként tisztelték, s róla szállott szájról szájra az ének. ${ }^{190}$

Bálványosváralján azonban nem mindenki tud Kossuthról, szerepéről, s vannak olyanok is, akik mást, például Mátyás királyt ültetik az emlékezet aranyszékébe. Ki volt hát a szabadító? „Az úrdógásoknak Mátyás király. Az hiszem, a vót” (Orbán István, 82 éves); „Mátyás felírta a marhákat jegyzékbe. Fellépett a kormány, a Mátyásé. Adja oda mindenki, akinek hat marhája van, kettőt... Aztán birtokot, hogy egyenlö legyen... Ez volt a paraszttörvény" (Szabó Bandi, 33 éves); „Nem könyvbül olvastam, öregrendű emberektöl hallottam, [nagy]apám mondta, aki felszabadult ember volt. Ő is átvette a földet. Azelőtt szolgalegény volt. Az Mátyás király idejében volt..." (Kovács Bandi, 61 éves) Ugyanez a Kovács András máskor viszont azt

\footnotetext{
${ }^{189}$ Uo. 43-981. doboz. 1804. nov. 3.

${ }^{190}$ A néprajzi súlypontú gazdag irodalom ismertetéséröl le kell mondanunk. A módszertani kérdéseket is felvető és igen értékes anyagot feltáró tanulmányok java része a váraljai gyüjtés után jelent meg. Néhány szerző nevét azonban meg kell említenünk: Dégh Linda, Ortutay Gyula, Kósa László, Katona Imre, Ferenczi Imre, Faragó József, Antal Árpád, Keszegh Vilmos és még sokan gazdagították a népi emlékezetben élő múlt irodalmát.
} 
mondotta: „48-as úgy vót: akkor Kossuth Lajos vót...” Nem bizonyos benne, és Mátyás királyt, valamint Kossuth Lajost egyaránt dicsőíti egy másik adatszolgáltató is. „Nem volt szabad senki. Az egész vagyon az úré volt. Mátyás király amikor még fiatal volt, akkor szabadultak fel." Majd kijavítja: „Nem is ö, hanem Kossuth szabadította fel a népeket” (Szilágyi János, 58 éves).

Molnár András (63 éves) már bizonyos abban, hogy Kossuthnak járó a köszönet: „Apám emlegette. Az uraké volt minden föld. Kossuth Lajos szabadította fel öket. Külső, belső föld mind az uraké volt. Mikor Kossuth felszabadította öket, mindenki azt a földet kapta, amit dolgozott: külsőt, belsőt” „Az úrbéreseket Kossuth szabadította fel - Mondotta Hajdu Márton (74 éves) is -, és akkor az a föld, amit müveltek, az az övék lett; azonban váltságdíjat kellett érte fizetni, de sokan ezt nem tudták megfizetni (az én édesanyám sem). Ezért egy részük otthagyta a földet, más részük pedig kiegyezett a földesúrral egy darab földterületen... és a belsőségben is kisebb házat kaptak...”

Pap Jenő (74 éves, úri rendbéli, de középiskolát nem végzett) az alszegi szép nagy ház tornácán magabiztosan jelenti ki: „Jött Kossuth, felszabadította őket. Debrecenben kimondotta: Respublica, nincs király."

Végezetül a felszegi (67 éves) Martonos Jánost kissé részletesebben is idéznők. Azon a régi vasárnapon is - mesélte - szokás szerint a templom előtt gyülekezett a jobbágysorsú váraljai nép, amikor egy ismeretlen ember érkezett a piacra. Ez az idegen Kossuth Lajos volt. (Lánya közbeveti, hogy „ü vót”. Petőfi nem lehetett, ő a „népdalköltő”.) Ennek a látogatásnak nyomán szabadultak fel az úrdolgások. A találkozás így történt:

„Ü - már mint Kusut - felöltözött szegény módra, s kiindult a kösségekbe.

A piacon megkérdezte az embertől:

- Hogy vattok, kollégák, hogy tudtok haladni előre a gazdáitokkal?

Csak hallgattak az emberek. Aztán az egyik azt mondta, s igaz volt a szava:

- Én jól.

$\mathrm{S}$ mert pénteken kapott verést, lehúzta a nadrágját, s megmutatta a fenekit. Mind tiszta ormó volt a teste! Igaz, hogy csak saroktól a fejiig volt, mert a fejit nem ütütték.

Kusut megnézte, s csak ennyit mondott:

- Na! Ne mondjatok senkinek semmit, de fel fogtok szabadulni!

Nem tudom, hány évre, hány hónapra, de fel is szabadultak."

Lányára nézett. Bizonyára Petőfire gondolt, a kalendáriumban írottakra, s ezekkel a szavakkal tett pontot a beszélgetésre:

„Akárki volt, áldott emlékü”191

\section{1848-49 története a váraljaiak emlékezetében}

A márciusi törvények, majd a kolozsvári diéta határozata nyomán a váraljai úrdolgás polgári értelemben vett parasztgazdává vált. Emlékeztek azonban rá, hogy erdőt nem kaptak, a szőlőkből is kisemmizték őket, hogy a fiskus taxásait megrövidítették és így tovább. Senki sem mesélt róla, de az írásos dokumentumokból tudjuk, hogy itt is késlekedtek a robot

${ }^{191}$ Vö. Imreh István: Kossuth Lajos Bálványosváralján. Utunk. III(1948) 5. sz. 
eltörlésével. Pap Márton, Vajda János, akik haszonbérlők voltak, törvénytelenül továbbra is szolgálatra kényszerítették az embereket, nagyra növelve a „magyarok” ellen bujtogatók sikerének esélyeit. ${ }^{192}$ Erről száz év múltán a falubeliek nem tudnak már semmit, mint ahogyan a nemzetőrség felállításáról sem. Holott Oroszhegyi (Szabó) Józsa (aki orvosként romániai tapasztalatairól 1942-ben könyv alakban megjelent értékes kéziratot hagy reánk), ${ }^{193}$ Bartalus István református pappal egyetemben 1848. május havában katonai egységbe szervez mintegy 150 váraljait. Fegyvert azonban nem kaptak, s így „hamar felhagytak a gyakorlatokkal”, s számuk is 25 -re csökkent. ${ }^{194}$

Időközben a krakkói születésủ Karl Urban báró alezredes, 1847 óta a II. román gyalogezred parancsnokának a vezetésével folyik a szabadságharc elleni propaganda, a Kossuth elleni agitáció, az „oszd meg és uralkodj” jelmondat cégére alatt folyó bujtogatás. ${ }^{195}$ Urban is lehetne tehát az emlékezők tudatában élő egyik személyiség, de nem tudnak róla, csak hadi népéről, a „lándzsásokról”. Pontosabban csak az egyik haszonbérlő-leszármazott emlékezett rá, aki úgy tudta, hogy Dés felgyújtására készült. (Jellemző, hogy Teleki Sándor visszaemlékezéseiben ${ }^{196}$ csak úgy tudja leírni a nevét, hogy megtoldja a „komisz” jelzővel.) Egészében véve tehát nem maradtak róla Váralja népében emlékfoszlányok sem, holott száz évvel azelőtt erőteljesen befolyásolta az itteni úrdolgások gondolkodását, sorsát. Urban a feudális struktúra feltámasztásának ígéretével titkon a birtokos urak rokonszenvét igyekezett megnyerni, a jobbágyságot pedig ugyanakkor ellenük, volt robotoltatóik ellen uszította. A botozásra, robotnövelésre, alávetettségre emlékező magyar jobbágyok közül is sokan hittek neki s zarándokoltak eligazításért Naszódra, amely különben a román parasztság „Mekkájává” vált.

Szeptember első napjaiban Urban már nyíltan szembefordult a forradalommal, felmondta az engedelmességet a magyar kormánynak. A döntő többségében magyar lakosságú Bálványosváralját a környékbeli románság részéröl ekkor végpusztulás fenyegette. A 25 före apadt nemzetőrség a „hazafias” pap vezetésével azonban éjjelente kivilágított templomtornyával jelezte, hogy kész a fegyveres ellenállásra. Nem is kockáztatták meg a támadást.

A szeptemberi napokban a sorozás is megindult. A váraljaiak most ezzel fordultak szembe, azért, mert a birtokosok gyüjtik ily módon a hadat a király ellen a felszabadulás okozta veszteségük megbosszulásáért. Ha felosztják a birtokokat, „mint a régi király akarja, akkor megyünk s adunk katonát, de addig nem” - ez volt a válaszuk. ${ }^{197}$

Száz év múltán a felszabadulásra, az úrdolgás világ megszüntére emlékezők szép és dicsőséges eseményként szólottak róla. Azonban a harcot, a fegyveres küzdelmet, ami az eredmények megtartásáért, az elért sikerek kiteljesítéséért folyt, valahogy különválasztva szemlélték; sokszor értetlenül, minősítésétől tartózkodva emlegették. Többen viszont határozottan úgy jellemezték, mint zavaros időket, nagy bolondságot, cudar világot, cifra világot, vagy leggyakrabban: „bolond világot”.

\footnotetext{
${ }^{192}$ Kádár József: Belső-Szolnok és Dobokamegye története. 1848-1849. Deésen 1890. 42.

${ }^{193}$ L. Oroszhegyi Józsa: Román élet. Kvár 1942. (Erdélyi Ritkaságok 5.)

${ }^{194}$ Kádár József: i. m. 46-47, 50.

195 Şotropa, Virgil: Comandanții regimentului grăniceresc năsăudean. Fraților Alexandru şi Ion I. Lăpedatu. Buc. 1936. 821-823.

${ }^{196}$ Teleki Sándor: Emlékezzünk régiekröl. Szerk. Csetri Elek. Buk. 1973, 1. pl. 252.

${ }^{197}$ Kádár József: i. m. 69.
} 
Az eddig elmondottak szerves folytatásaként és egyben a zaklatott, tévelygésekkel teli „bolond világ” képzet jobb megértése végett kell elsőként idéznünk „a pap történetét”. Kádár József így írja le az eseményeket. „Református váraljai magyar lakosok, Szabó Istvánnal, Deák Imrével az élen, elfogták papjukat, Bartalus Istvánt Békési Zsigmond kántortanítót, két esküdtet, továbbá két nemzetőrt, és megkötözve vitték Málomon át Tekébe Axinte elé." (Így cselekedtek kántorukkal - szintén jutalom reményében - a szásznyíresiek is.) „Az elhurcoltakat ólformába zárták, hol rajtok kívül mintegy 52 fogoly volt.” Innen Szászrégenbe vitték, majd a székelyek támadása után hazabocsátották őket. ${ }^{198}$ Még csak azt füznők hozzá, hogy Bartalus 1857-ig lelkésze volt a községnek.

Ioan Rus (görög katolikus, 72 éves) úgy tudja, hogy „48-ba bétötték a papot az ólba s dióbéllel hizlalták. Itt Váralján történt. Aztán elvitték. Mindenfelé a községekbe akkor vitték [a papokat]. Akkor bolond világ volt. Elfogták a nagy urakat. El is felejtettem, megölték-e a papot, de elvitték, azt jól tudom. Biza bétötték az ólba."

Pap Jenő úgy tudja, hogy a papot és a kurátort Désig vitték összekötözött kezekkel, itt „valami disznóolba tették”. Urban kieresztette. „Bizony ilyenek voltak a váraljaiak akkor is. Saját magyar hívei ilyet tettek a pappal!” Arra a kérdésre, hogy miért csinálták: „Ki tudja, miért? Pedig nagyon szociálista volt, uszította a birtokosok ellen az embereket. Biztos annak élvezte a gyümölcseit!"

„A papot elvitték. Bézárták az ólba - meséli Orbán István (82 éves) -, vót véle presbiter, ott is örizte, adott enni s pipát. A láncsások fogták el, de csak eleresztették." A papot nem ölték meg, mondja Vas István (55 éves): „A papot akkor vagy Tekébe, vagy Buzába vitték el az ólba, s Nagy Pisti szabadította ki. Elhozta ökreit is.” Miklós Sándor (84 éves) szerint: „A papot bezárták az ólba, nem tudom, hová. Kuthán oláh, az zárta bé. Váraljai vót. Cudar világ vót."

Emlékezetesek maradtak a november végi napok is, mert Urban a szolnok-dobokai lándzsásokat, népfelkelőket - magyarokat is - Kolozsvár elfoglalása után Szamosfalváról hazabocsátotta. „Mihailás vezérelte őket vissza az oláhokkal együtt”, s útjokat Bálványosváralján vették keresztül, „ahol több hordó bort szekerekre raktak, velök vígan Málom felé távozának” - írja Kádár József. ${ }^{199}$

A Pap Márton pincéit a váraljaiak szerint valóban feltörték, hatalmas hordókat hoztak ki azokból és gurították le a lakomázóknak. Olyan régi, erős hordókat, hogy egy abroncsuk sem hullott le. Ökröket is zsákmányoltak, hajtottak el. Ellenállásról szó sem lehetett, csak Nagy Pista, a „kiskirály” szállott szembe velük és vált a váraljai nép számára a 48-as harci dicsőség talán egyetlen legendás hősévé. (Holott 1849-ben azután „Bem apó” vezetésével több mint 150-en harcoltak.)

Nagy István családfáját 1715-től felderítve kisnemesi és darabonti rokonságot állapíthatunk meg. Ő azért „kiskirály” az adatszolgáltatók többsége szerint, mert „ő volt a nemesek feje”, tehát a szabad státusbeliek hadnagya.

Ellentmondó, időkeretet megmásító, naiv, mesebeli elemekkel átszőtt apró történetek keringenek róla. Ilyenszerüek is: „Kiskirálynak nevezték, mert ezen a vidéken, abban a bonyodalomban, 1848-ban, kikiáltotta magát. A románok tartottak tőle. A váraljaiak nagyon szerették öt. A környéken mindenki ismerte.” „Kossuth idejébe volt ő. Amikor átvonulás volt. Ö mindig a »Pali bokrába« volt. Onnan nézte, hogy elhajtották ökreit.” „Bort, mindent vittek

\footnotetext{
${ }^{198}$ Ua. $106-107$.

${ }^{199}$ Ua. 119.
} 
el a szekerekkel” (Vas István, 55 éves). „Az akkor volt, mikor az a bolond világ volt. Egyik falu üzte a másikat. Nagy Pisti, akié az erdő volt, amit ma Nagy Pista bokrának hínak, oda futott az erdőben. Jött az ármádia láncsákkal. Mik voltak, nem tudhatom. Keresték a királyt. Az ökrit mikor vitték, ezt kiáltotta: Ne hadd Isten, mert viszik el az ökrömet! De Isten nem segítette. Vitték ki a bort s az ökröt a falu végire” (Orbán István, 82 éves). „Király is vót! Kiskirály! Nagy Pista, az vót a király. Mikor jött az ármádia, a királyt kiüzték a láncsások. Keresték a királyt, de elbútt az erdőben. A király borát odavitték a falu végihez, ott volt a láger, ott itták a borát. A kiskirály kiváló ember vót. A kuruc világban" (Martonos János, 64 éves). „Nagy Pista, amikor itt voltak, nem mert eléjönni. Pedig amíg bé nem jöttek, fente a nemes rozsdás kardját, hogy így meg úgy lesz. Igaz, hogy mivel az ökrit ellopták, hozott négyet helyette...” (Pap Jenő, 74 éves)

Unokája, Nagy Sándor (73 éves) szerint: „Király, kapitány, hadnagy, ki voltak akkor nevezve. Bolond világ volt, akkor kellett.” Magas, száraz ember, „fáin” ember volt. „Tudott is futni, mint a fegyvergolyó. Sokszor űzőbe vették, de megfogni nem tudták. A Bátony utca végén szinte elérte a lándsa, de mégis kiért a tetöre. Amikor kiérkezett, megütötte a sarkát, s azt kiáltotta: most lüjjetek!” Amikor egy csoport váraljai közé veszett kutya szökött, ,,az öregnél puska volt, egybe úgy kilütte a kutyát, hogy no”. Pali bokrát róla nevezték el Nagy Pisti bokrának.

Van, aki 66-beli (?) tatárfutás idejére helyezi az eseményeket, Szabó Imre (69 éves) pedig dicsérőleg említi, hogy: „Betyárvezér volt. Csapatjával járt rabolni a vidéket. Mikor jöttek, nem volt szabad elzárni semmit, el kellett őket látni mindennel.” Vetélytársa is volt, Vas Pál nevü, akinek a „bérelt” csapatával Nagy Pistáék a Kertmeg utca feletti kiserdőben csatáztak.

Nagy, hosszú kardját - ott hányódott a fia kamrájában - többen is látták. Deák János (48 éves) pedig megőrizte ólom pecsétgyürüjét, amelyen ötágú korona alatt az $\mathrm{N}$ és az I betü fonódott össze.

Többen váraljai magyarok nem tudják, milyen nemzetbéli volt a lándzsás. Román adatszolgáltatók azonban igen, és a legterhesebb emlékek hordozója, Rus bácsi is: „48-ban jártak a románok láncsával. Amelyik ellenség volt, azt megölték. Anyám mesélte (magyar asszony volt). Anyám apja is nemes volt. Bújtak akkor. Rea tették a szegeletbe a gyermekekre a teknőt. A gyermekeket éppen felláncsázták. Vitás világ volt. Bolond világ. Most csak rossz a világ, de nem bolond."

Tudnak négyéves kislányról, aki Avram Iancu ölében ülve mondja: „Látod, édesapámat megölik, s én mégse sírok.” „Iancu” meg is akarta menteni, de Incze uram akkor már halott volt. Pap Mártont viszont a két Szabó, Sándor és István akarta kivégezni, amiért 48 után a bosszút álló bérlő-birtokos a templom előtt botoztatta meg őket.

Bindea Néta (50 éves) a „muszkákról” is tud: „Az oroszok láncsákkal jöttek. Kicsiny gyermekeket húztak láncsára, és Nagy Pista kiskirály mind a hat ökrét elhajtották. Nagy Pista az erdőkbe bujdosott, és az oroszok mindenütt ordítva kérdezték: undgye imperátyu"?

Lezárni a beszámolót beható elemzéssel és értékeléssel kellene. A tanulságok azonban így is levonhatók. Az úrdolgás világ szomorú hagyománya ott élt a váraljai nép emlékezetében. Az örömteli felszabadulásé szintén, és természetesen a Kossuth Lajosé is. 